Article

\title{
Cause of Color Modification in Tanzanite after Heat Treatment
}

\author{
Teerarat Pluthametwisute ${ }^{1, *}$, Bhuwadol Wanthanachaisaeng ${ }^{2}$, Chatree Saiyasombat ${ }^{3}$ (D) and \\ Chakkaphan Sutthirat ${ }^{1}$
}

1 Department of Geology, Faculty of Science, Chulalongkorn University, Bangkok 10330, Thailand; chakkaphan.s@chula.ac.th

2 Gem and Jewelry Program, College of Creative Industry, Srinakharinwirot University, Bangkok 10110, Thailand; bhuwadol@g.swu.ac.th

3 Synchrotron Light Research Institute (Public Organization), Nakhon Ratchasima 30000, Thailand; chatree@slri.or.th

* Correspondence: T_pluthametwisute@hotmail.com

Academic Editor: Michael Bolshov

Received: 11 July 2020; Accepted: 14 August 2020; Published: 16 August 2020

\begin{abstract}
Natural tanzanites usually show strongly trichroic coloration from violet to blue, and brown colors in different directions. However, this characteristic is easily changed to violet-blue dichroism after heat treatment. Moreover, the cause of color modification after heating is still controversial. A few researchers have previously suggested that trace amounts of either vanadium or titanium substituted in aluminum site should be the main determinant of color after the heat treatment. Alteration of either $\mathrm{V}^{3+}$ to $\mathrm{V}^{4+}$ or $\mathrm{Ti}^{3+}$ to $\mathrm{Ti}^{4+}$ may relate to light absorption around 450-460 nm, which is the main cause. UV/vis/NIR absorption spectroscopy and X-ray absorption spectroscopy (XAS), a utility of synchrotron radiation, were applied for this experiment. As a result, the violet-blue absorption band (centered around $450-460 \mathrm{~nm}$ ) as well as green absorption band (centered around $520 \mathrm{~nm}$ ) were obviously decreased along the c-axis after heating, and XAS analysis indicated the increasing of the oxidation state of vanadium. This result was well supported by the chemical composition of samples. Consequently, vanadium was strongly suggested as the significant coloring agent in tanzanite after heat treatment.
\end{abstract}

Keywords: tanzanite; heat treatment; zoisite; color

\section{Introduction}

Tanzanite, a violet-blue vanadium-bearing variety of zoisite $\left(\mathrm{Ca}_{2} \mathrm{Al}_{3}\left[\mathrm{Si}_{2} \mathrm{O}_{7}\right]\left[\mathrm{SiO}_{4}\right] \mathrm{O}(\mathrm{OH})\right)[1]$, has been long known and has become a highly demanded precious stone in the world gem market owing to its fantastic color appearance. Natural tanzanites usually show strong trichroism between violet, blue, and brown (or green) colors (Figure 1). Tanzanite was first discovered in 1967 [2] at Merelani area, north-eastern Tanzania (East Africa), by Jumanne Ngoma, a gypsum miner who was officially acknowledged by the Tanzanian government. The deposit only covers around 7 kilometers and its estimated life expectancy for mining is, unfortunately, less than 20 years [3]. Moreover, natural high-quality violet-blue colored tanzanites are rare; therefore, heat treatment has been applied to lower quality stones owing to the high demand in the market. 


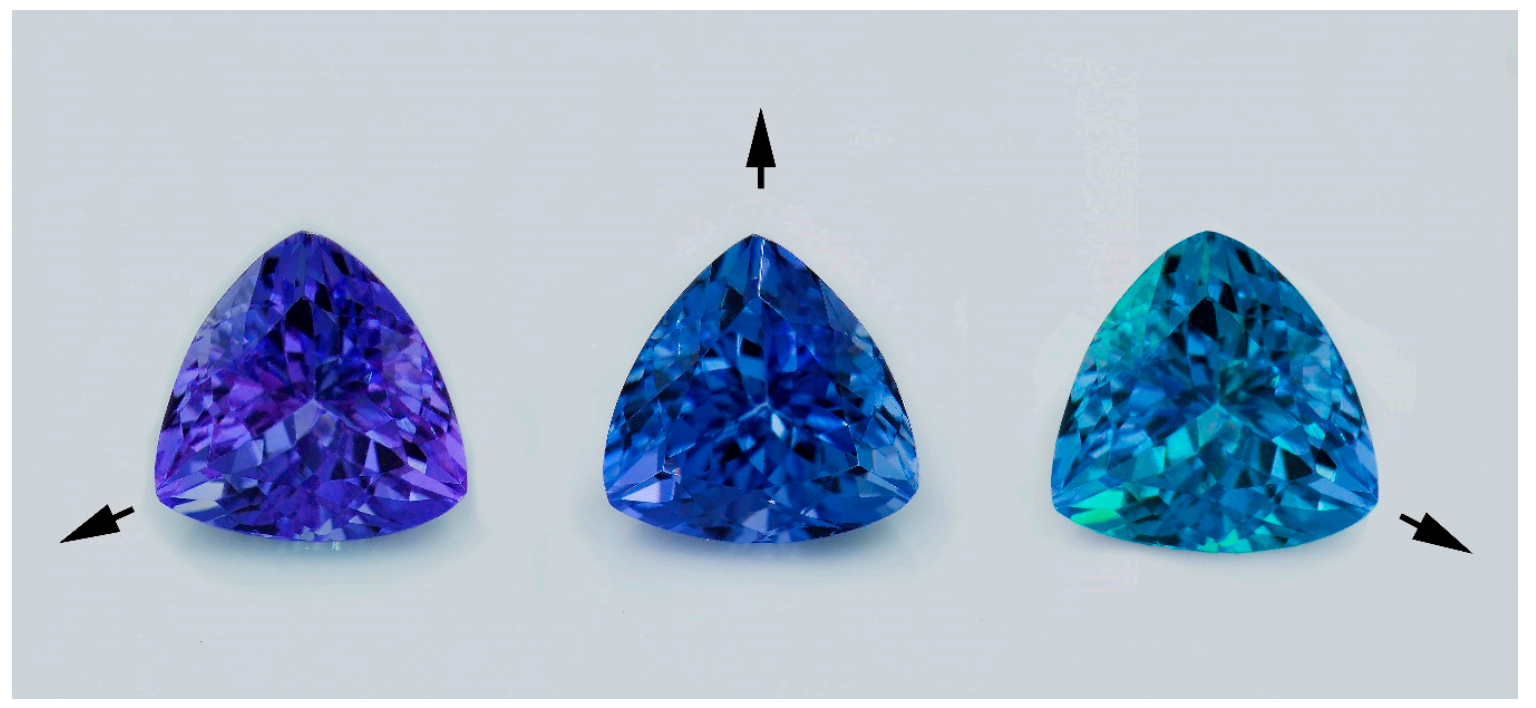

Figure 1. Trichroism of a natural tanzanite rotated in three directions showing violet, blue, and green pleochroic colors (photo by T. Sripoonjan, GIT).

Zoisite, including tanzanite variety, is an orthorhombic sorosilicate mineral whose ideal formula can be defined as $\mathrm{A}_{2} \mathrm{M}_{3} \mathrm{Si}_{3} \mathrm{O}_{12} \mathrm{OH}$ [4], where $\mathrm{A}$ sites are generally substituted by divalent cations (e.g., $\mathrm{Ca}, \mathrm{Mn}, \mathrm{Sr}, \mathrm{Pb}$ ), while $\mathrm{M}$ sites are mainly occupied by trivalent cations (e.g., $\mathrm{Al}, \mathrm{Fe}, \mathrm{Mn}, \mathrm{Cr}$, and $\mathrm{V}$ ) [5-7]. Its structure contains the base of edge sharing octahedral (M1,2) chain linked by double $\mathrm{Si}_{2} \mathrm{O}_{7}$ (T1, T2) and single $\mathrm{SiO}_{4}$ (T3) tetrahedra. This edge sharing octahedral chain in zoisite also has additional M3 octahedra attaching on one side of the chain [7] (Figure 2). The structure of zoisite is slightly different from clinozoisite (a member of epidote supergroup), with the additional M3 octahedra attaching on both sides along the b-axis of the octahedral M1 chain and the octahedral M2 chain being isolated from the M3-combined M1 chain (see also Figure 2). According to this information, the Commission on New Minerals, Nomenclature, and Classification of the International Mineralogical Association (IMA) has recently defined all members of epidote supergroup as monoclinic minerals, and thus tanzanite, a variety of orthorhombic sorosilicate zoisite, no longer belongs to the epidote supergroup [8-10]. 
a)

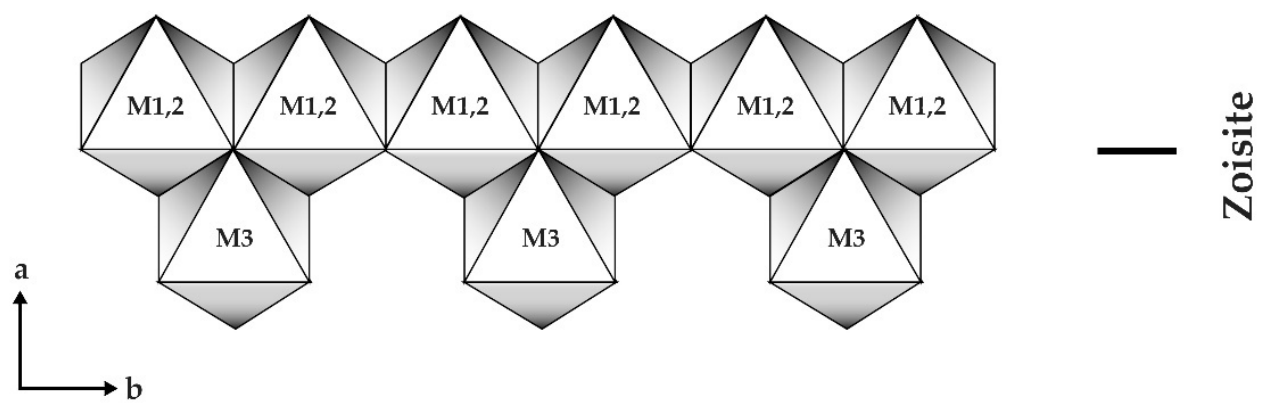

b)

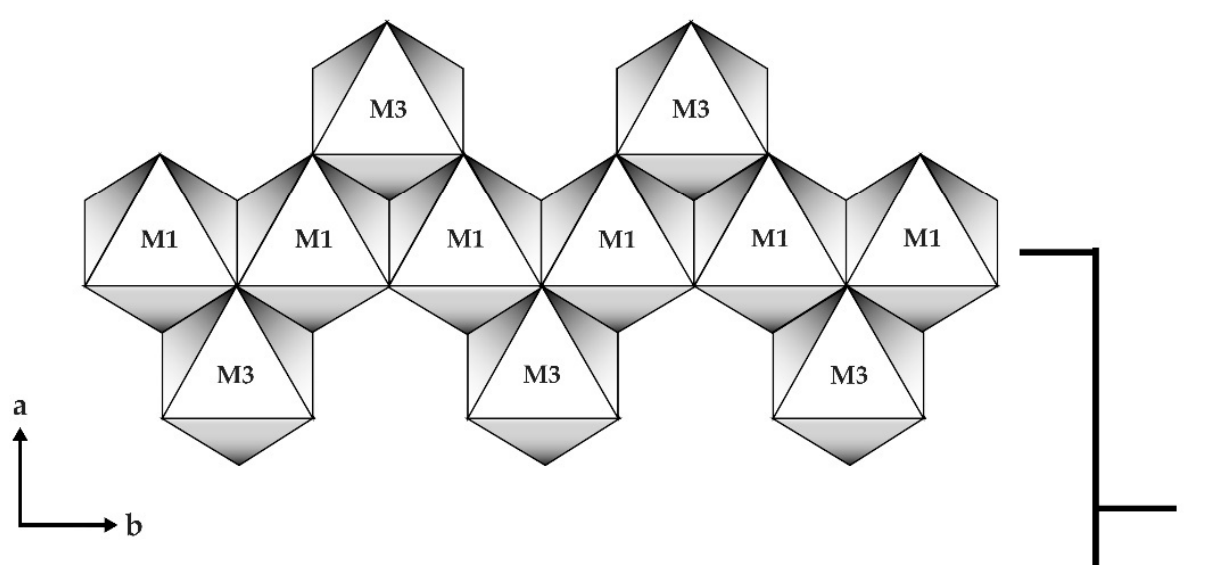

c)

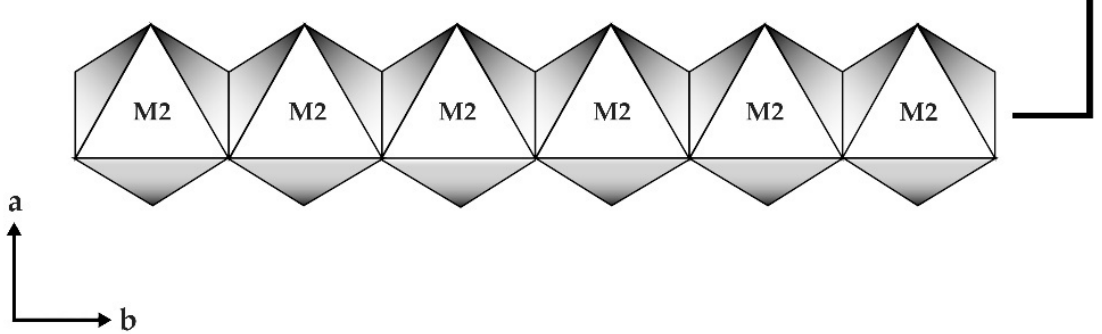

Figure 2. (a) Zoisite octahedral chain (M1, 2) combined with additional octahedra (M3) on only one side along b-direction, whereas (b) additional octahedra (M3) located on both sides of clinozoisite octahedral chain (M1) with (c) isolated octahedral chain (M2) (modified after Franz and Liebscher [7]).

Tanzanite has been heated to improve the color to sapphire-like blue color, which is highly demanded in the market $[2,11]$. It is believed that the violet-blue color in the tanzanites is owing to the presence of vanadium, which replaces aluminum in the octahedral site [3,5,12-17]. Heating tanzanite at approximately $\sim 500^{\circ} \mathrm{C}$ usually produces the disappearance of the yellow color in that particular direction in which the absorption around $450-460 \mathrm{~nm}$ is decreased, and alteration of pleochroism from trichroic to dichroic violet to blue color $[3,13,14,17]$. Heating tanzanite at too low or too high a temperature may lead to never reaching the desirable color alteration; no color alteration is observed below $250{ }^{\circ} \mathrm{C}$ [13], whereas color appears to be faded at a high temperature [3]. In situ heating spectroscope was used to reveal the optimum temperature $\left(550^{\circ} \mathrm{C}\right)$, which causes the disappearance of the absorption around 450-460 $\mathrm{nm}$ [3]. Color alteration behavior after heat treatment can also be observed in other gemstones. For example, blue intensification and removal of green tint in 
blue-colored variety (aquamarine) of beryls were performed by heating at $300-700{ }^{\circ} \mathrm{C}$, leading to the reduction of $\mathrm{Fe}^{3+}$ to $\mathrm{Fe}^{2+}$. Consequently, $\mathrm{Fe}^{3+}$ absorption bands at 375 and $425 \mathrm{~nm}$ are decreased, while $\mathrm{Fe}^{2+}$ band at $810 \mathrm{~nm}$ is significantly intensified. However, heating aquamarines at higher temperature (e.g., $1100^{\circ} \mathrm{C}$ ) may lead to an opaque appearance, which relates to the disappearance of the $810 \mathrm{~nm}$ absorption band [18]. Another example is in diaspore (zultanite), where the chromophores involved in the variation in the color are owing to the presence of Ti-Fe and are associated with the intervalence-charge-transfer mechanism [19].

However, coloration in tanzanite after heat treatment has been still a questionable subject for decades. Previous researchers speculated that coloration of heated tanzanite is owing to oxidation changing of either vanadium or titanium. Vanadium may have been oxidized from $\mathrm{V}^{3+}$ to $\mathrm{V}^{4+}$ after heat treatment [5,14]; however, Olivier [3] argued that the coloration of tanzanite after heat treatment is owing to an oxidizing of titanium from $\mathrm{Ti}^{3+}$ to $\mathrm{Ti}^{4+}$. Moreover, a more recent inconsistency by Smith [16] quoted that the change in color of brown tanzanite after heating is attributed to a conversion of $\mathrm{V}^{4+}$ to $\mathrm{V}^{3+}$, as well as Bocchio et al. [17], who also introduced that the V/Ti ratio should play an important role in the coloration of tanzanite without any concern about oxidation states of both elements in natural and heated tanzanites. Since then, the controversial topic of oxidation states of the color-causing element in tanzanite has still not been settled.

X-ray absorption spectroscopy (XAS), a synchrotron radiation utility, is a potential atomic probe technique that is sensitive to the oxidation state and local structure of absorbing element. XAS is basically divided into two regions: X-ray absorption near edge structure (XANES) and extended X-ray absorption fine structure (EXAFS). XANES is a useful spectroscopic technique to determine the oxidation state and structural symmetry, while EXAFS is used to explore the local structure of the absorbing atom including the distance of neighboring atoms, coordination number, and disorder of neighboring atoms. A probed element with various oxidation states and local structure will affect the shift of the absorption edge (edge energy, E0) [20-23] and characteristic XANES features. Therefore, this study is attempted to ascertain the main cause of modified coloration in tanzanite after heat treatment. Changing in oxidation states of vanadium and titanium is the focus in this study.

\section{Results}

\subsection{General Properties}

The physical properties of all tanzanite samples are summarized in Table 1 . They ranged from 0.565 to 1.26 carats in weight with specific gravity (S.G.) of 3.32-3.38. Refractive indices (R.I.) and birefringence fell within the ranges of 1.691-1.701 and 0.08-0.09, respectively. All samples were inert under UV lamp. Their natural trichroic colors and dichroic colors after heating observed along different directions are presented in Figure 3.

Table 1. General properties of tanzanite samples in this study.

\begin{tabular}{cccccc}
\hline Sample/Properties & T04 & T06 & T09 & T11 & T12 \\
\hline Refractive Indices & $1.692-1.700$ & $1.691-1.700$ & $1.691-1.700$ & $1.693-1.701$ & $1.692-1.701$ \\
Birefringence & 0.008 & 0.009 & 0.009 & 0.008 & 0.009 \\
Specific Gravity & 3.33 & 3.35 & 3.37 & 3.32 & 3.38 \\
UV Fluorescence & Inert & Inert & Inert & Inert & inert \\
\hline
\end{tabular}




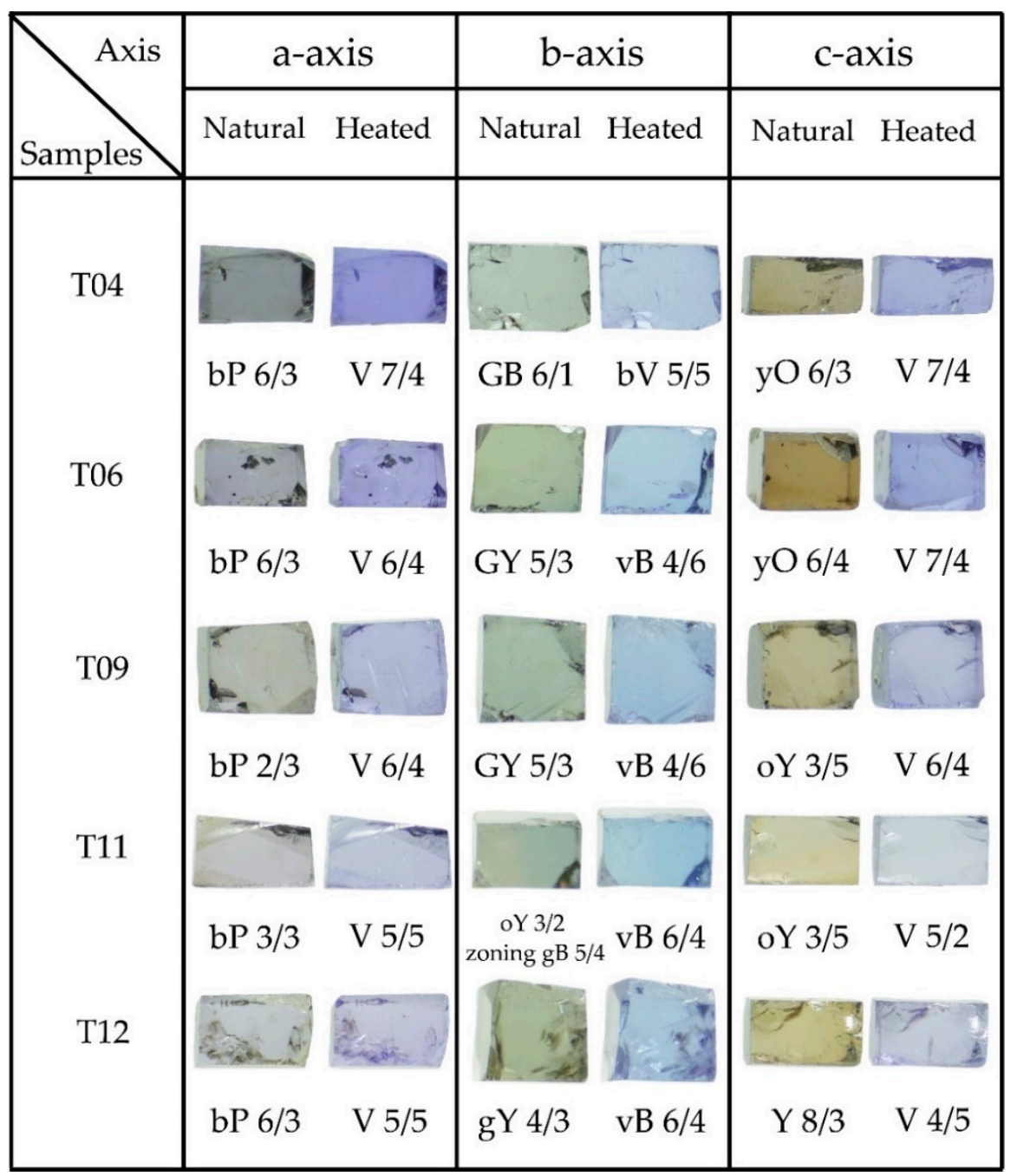

Figure 3. All tanzanite samples show natural trichroic colors including purple, green, and yellow dominating along the directions of a-, b-, and c-axes, respectively, as suggested by $[3,13,14,17]$; they turned to dichroic coloration between violet color (along the a- and c-axes) and blue color (along the b-axis) after the heating experiment.

\subsection{Chemical Compositions}

Major and trace compositions, resulting from EPMA analyses, are presented in Table 2. A.P.F.U. were recalculated on the basis of 13 oxygen atoms. Three analytical spots were carried out on the $\mathrm{C}$-axis (yellowish color). $\mathrm{SiO}_{2}, \mathrm{Al}_{2} \mathrm{O}_{3}$, and $\mathrm{CaO}$ ranged from about 39.0 to $40.5 \mathrm{wt} \%, 33.0$ to $34.0 \mathrm{wt} \%$, and 24.0 to $24.5 \mathrm{wt} \%$, respectively. $\mathrm{V}_{2} \mathrm{O}_{3}$ content yielded $<0.5 \mathrm{wt} \%$, whereas $\mathrm{TiO}_{2}$ content was even lower than $0.05 \mathrm{wt} \%$, and other trace elements including $\mathrm{MgO}, \mathrm{Cr}_{2} \mathrm{O}_{3}, \mathrm{FeO}, \mathrm{MnO}, \mathrm{Na}_{2} \mathrm{O}$, and $\mathrm{K}_{2} \mathrm{O}$ were negligible and mostly lower than $0.1 \mathrm{wt} \%$. Apart from the major contents of $\mathrm{Si}, \mathrm{Al}$, and $\mathrm{Ca}$, the EPMA data also indicated that $\mathrm{V}$ is the most significant trace chromophore in these samples. 
Table 2. Electron probe microanalyzer (EPMA) analyses of major and trace compositions of tanzanite samples under this investigation.

\begin{tabular}{|c|c|c|c|c|c|c|c|c|c|c|c|c|c|c|c|}
\hline Sample/Oxides (wt \%) & T04_1 & T04_2 & T04_3 & T06_1 & T06_2 & T06_3 & T09_1 & T09_2 & T09_3 & T11_1 & T11_2 & T11_3 & T12_1 & T12_2 & T12_3 \\
\hline $\mathrm{SiO}_{2}$ & 39.78 & 39.04 & 39.04 & 40.02 & 40.21 & 39.79 & 39.86 & 39.42 & 39.50 & 40.12 & 40.49 & 39.43 & 39.46 & 39.77 & 39.25 \\
\hline $\mathrm{TiO}_{2}$ & 0.00 & 0.03 & 0.00 & 0.03 & 0.00 & 0.00 & 0.05 & 0.00 & 0.00 & 0.00 & 0.02 & 0.00 & 0.00 & 0.00 & 0.03 \\
\hline $\mathrm{Al}_{2} \mathrm{O}_{3}$ & 33.48 & 33.02 & 33.47 & 33.19 & 33.21 & 33.99 & 33.21 & 33.72 & 33.83 & 33.23 & 33.17 & 33.09 & 33.42 & 33.26 & 33.25 \\
\hline $\mathrm{V}_{2} \mathrm{O}_{3}$ & 0.39 & 0.43 & 0.38 & 0.35 & 0.38 & 0.39 & 0.29 & 0.20 & 0.29 & 0.25 & 0.25 & 0.25 & 0.18 & 0.06 & 0.21 \\
\hline $\mathrm{Cr}_{2} \mathrm{O}_{3}$ & 0.00 & 0.07 & 0.08 & 0.05 & 0.02 & 0.08 & 0.00 & 0.07 & 0.00 & 0.02 & 0.00 & 0.05 & 0.00 & 0.00 & 0.00 \\
\hline $\mathrm{FeO}$ & 0.00 & 0.00 & 0.00 & 0.03 & 0.00 & 0.01 & 0.00 & 0.00 & 0.00 & 0.06 & 0.00 & 0.03 & 0.03 & 0.00 & 0.04 \\
\hline $\mathrm{MnO}$ & 0.00 & 0.01 & 0.00 & 0.00 & 0.02 & 0.00 & 0.06 & 0.03 & 0.03 & 0.02 & 0.00 & 0.00 & 0.01 & 0.01 & 0.01 \\
\hline $\mathrm{MgO}$ & 0.05 & 0.04 & 0.03 & 0.05 & 0.03 & 0.05 & 0.04 & 0.05 & 0.05 & 0.02 & 0.01 & 0.01 & 0.05 & 0.05 & 0.04 \\
\hline $\mathrm{CaO}$ & 24.26 & 24.28 & 24.12 & 24.38 & 24.56 & 24.45 & 24.64 & 24.34 & 24.34 & 24.47 & 24.43 & 24.37 & 24.33 & 24.35 & 24.55 \\
\hline $\mathrm{Na}_{2} \mathrm{O}$ & 0.00 & 0.01 & 0.00 & 0.00 & 0.01 & 0.00 & 0.00 & 0.00 & 0.02 & 0.00 & 0.02 & 0.00 & 0.01 & 0.01 & 0.00 \\
\hline $\mathrm{K}_{2} \mathrm{O}$ & 0.01 & 0.00 & 0.01 & 0.01 & 0.00 & 0.00 & 0.01 & 0.01 & 0.00 & 0.00 & 0.01 & 0.02 & 0.01 & 0.01 & 0.00 \\
\hline Total & 97.97 & 96.94 & 97.13 & 98.11 & 98.44 & 98.76 & 98.15 & 97.84 & 98.06 & 98.19 & 98.41 & 97.94 & 97.48 & 97.52 & 97.38 \\
\hline \multicolumn{16}{|c|}{ Atom Per Formula Unit based on 13 oxygens } \\
\hline $\mathrm{Si}$ & 3.128 & 3.110 & 3.101 & 3.144 & 3.149 & 3.107 & 3.134 & 3.107 & 3.105 & 3.149 & 3.168 & 3.128 & 3.120 & 3.141 & 3.112 \\
\hline $\mathrm{Ti}$ & 0.000 & 0.002 & 0.000 & 0.002 & 0.000 & 0.000 & 0.003 & 0.000 & 0.000 & 0.000 & 0.001 & 0.000 & 0.000 & 0.000 & 0.002 \\
\hline $\mathrm{Al}$ & 3.104 & 3.100 & 3.132 & 3.073 & 3.065 & 3.127 & 3.077 & 3.132 & 3.135 & 3.074 & 3.059 & 3.093 & 3.115 & 3.096 & 3.107 \\
\hline $\mathrm{V}$ & 0.025 & 0.027 & 0.024 & 0.022 & 0.024 & 0.024 & 0.018 & 0.013 & 0.018 & 0.016 & 0.016 & 0.016 & 0.011 & 0.004 & 0.013 \\
\hline $\mathrm{Cr}$ & 0.000 & 0.005 & 0.005 & 0.003 & 0.001 & 0.005 & 0.000 & 0.005 & 0.000 & 0.001 & 0.000 & 0.003 & 0.000 & 0.000 & 0.000 \\
\hline $\mathrm{Fe}$ & 0.000 & 0.000 & 0.000 & 0.002 & 0.000 & 0.001 & 0.000 & 0.000 & 0.000 & 0.004 & 0.000 & 0.002 & 0.002 & 0.000 & 0.002 \\
\hline $\mathrm{Mn}$ & 0.000 & 0.001 & 0.000 & 0.000 & 0.002 & 0.000 & 0.004 & 0.002 & 0.002 & 0.001 & 0.000 & 0.000 & 0.001 & 0.001 & 0.001 \\
\hline $\mathrm{Mg}$ & 0.005 & 0.005 & 0.003 & 0.006 & 0.004 & 0.006 & 0.004 & 0.006 & 0.006 & 0.002 & 0.001 & 0.001 & 0.006 & 0.006 & 0.004 \\
\hline $\mathrm{Ca}$ & 2.045 & 2.072 & 2.053 & 2.052 & 2.061 & 2.045 & 2.075 & 2.055 & 2.050 & 2.058 & 2.048 & 2.071 & 2.061 & 2.060 & 2.086 \\
\hline $\mathrm{Na}$ & 0.000 & 0.002 & 0.000 & 0.000 & 0.002 & 0.000 & 0.000 & 0.000 & 0.003 & 0.000 & 0.003 & 0.001 & 0.001 & 0.001 & 0.000 \\
\hline K & 0.001 & 0.000 & 0.001 & 0.001 & 0.000 & 0.000 & 0.001 & 0.001 & 0.000 & 0.000 & 0.001 & 0.002 & 0.001 & 0.001 & 0.000 \\
\hline Total & 8.308 & 8.323 & 8.319 & 8.305 & 8.307 & 8.315 & 8.316 & 8.319 & 8.320 & 8.306 & 8.296 & 8.317 & 8.317 & 8.310 & 8.327 \\
\hline
\end{tabular}




\subsection{Heat Treatment}

As expected, heating with optimum temperature $\left(550{ }^{\circ} \mathrm{C}\right)$ dramatically effected the colors of tanzanite in all directions (Figure 3). Yellow tints in the C-axis were obviously removed after the heating experiment. Figure 3 also presents the color codes of natural colors and colors after heat treatment along the three main directions; for instance, the sample T04 yielded color alteration from yellowish orange $(\mathrm{yO} 6 / 3)$ to violet $(\mathrm{V7} / 4)$ along the c-axis, green-blue (GB 6/1) to bluish violet (bV 6/5) along the b-axis, and bluish purple (bP 6/3) to violet (V7/4) along the a-axis. In general, their trichroic colors appeared to be changed to dichroic colors after heat treatment. The C-axis direction always shows the strongest color modification compared with the other direction.

\subsection{UV/VIS/NIR Spectroscopy}

UV/vis/NIR spectroscopy revealed a representative spectra of natural and heated tanzanite sample (Figure 4). This natural tanzanite sample T04 showed the highest absorption band with a peak at about $460 \mathrm{~nm}$ (violet-blue range), particularly in the c-axis, whereas the absorption band with a peak at around 585-600 nm (yellow range) appeared to be the most typical in all directions. In fact, the absorption band with a peak at $460 \mathrm{~nm}$ also presented slightly in the a- and b-axes, but this absorption was significantly decreased in all directions after heating. On the other hand, the absorption band (peak around 585-600 nm) still remained as shown in Figure 4.

In summary, decreasing the absorption band with a peak at $460 \mathrm{~nm}$ (violet to blue range) was obviously observed in all directions after heating experiment (Figure 4), whereas the absorption band with a peak around 585-600 nm was unchanged. Only in c-axis, was the absorption band with a peak at $585 \mathrm{~nm}$ slightly increased after heating. It should be notified that natural tanzanite usually shows an important absorption band with a peak around $460 \mathrm{~nm}$, which is possibly caused by either vanadium or titanium, as suggested by previous researchers [3,5,12-17]. 
a)

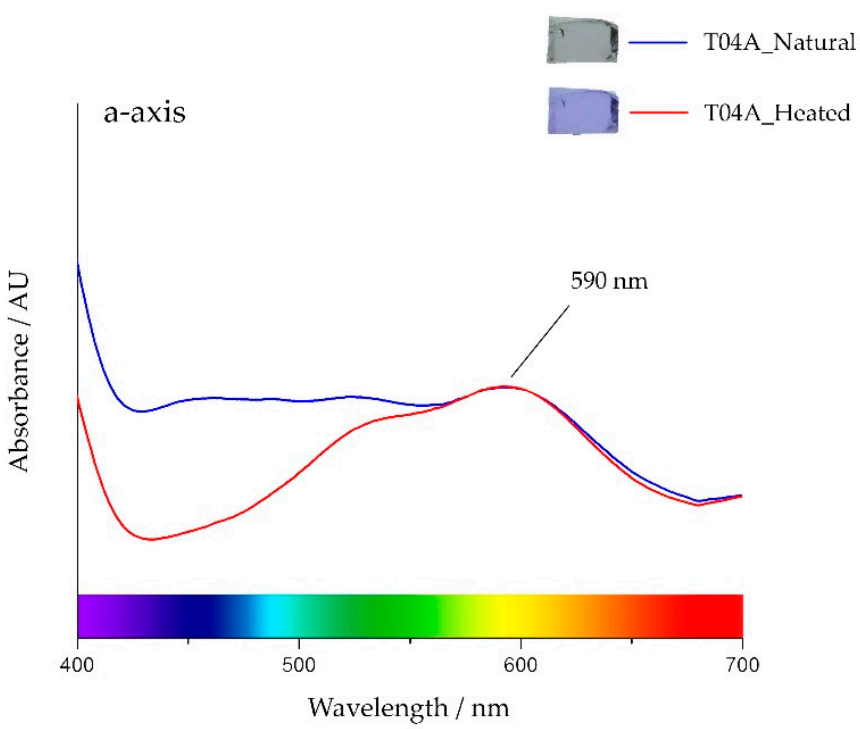

b)
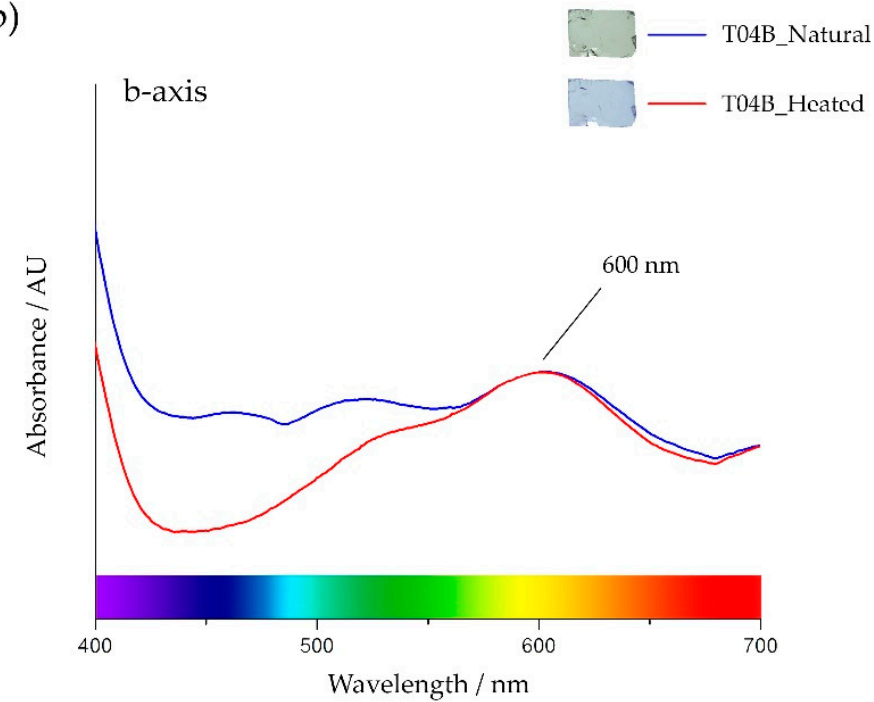

c)

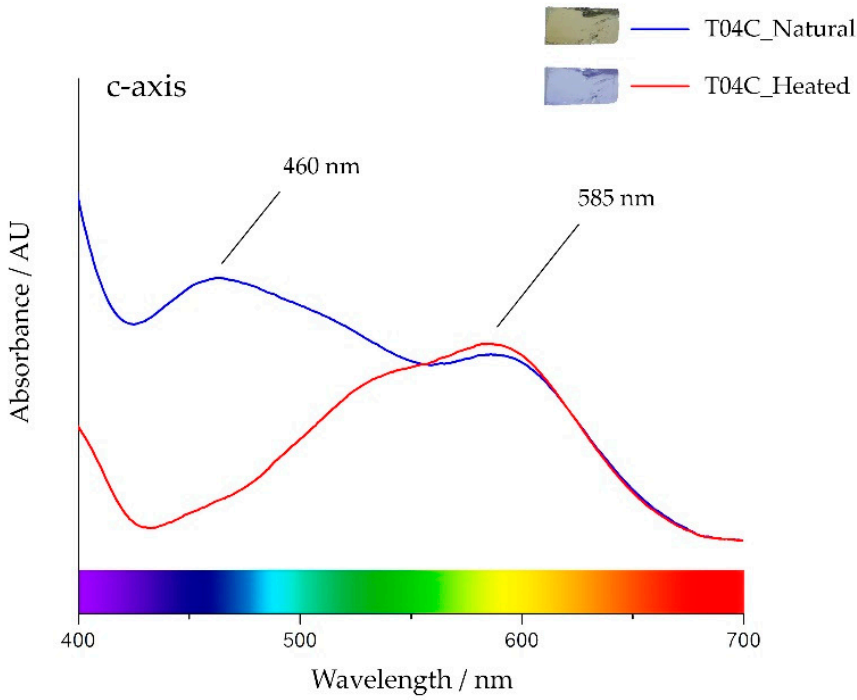

Figure 4. Representative absorption spectra of natural (blue spectrum) and heated (red spectrum) along the a-axis (a), b-axis (b), and c-axis (c) of a tanzanite sample (T04) (visible spectrum modified after Nassau [24]). 


\subsection{X-Ray Absorption Spectroscopy (XAS)}

Edge energy (E0) data in the natural tanzanite were increased to higher energy of vanadium after heat treatment, as summarized in Table 3. For instance, edge energy of natural tanzanite sample T06 was $5478.95 \mathrm{eV}$ and subsequently reached up to $5479.15 \mathrm{eV}$. On the other hand, titanium in the same sample appeared to be decreased in edge energy from $4981.00 \mathrm{eV}$ in natural tanzanite to $4980.70 \mathrm{eV}$ after heating experiment (Table 3). All analytical data of E0 obtained from all samples are compared in the graphic presentation in Figures 5 and 6 for $\mathrm{V}$ and $\mathrm{Ti}$, respectively. Most samples obviously showed increasing edge energy of vanadium and decreasing edge energy of titanium. The change in edge energy refers to changing of the oxidation state; the higher energy indicates the higher oxidation state [20]. Therefore, $\mathrm{V}$ tended to oxidize after heating at $550{ }^{\circ} \mathrm{C}$ in atmospheric environment, whereas Ti behaved in the other way.

Table 3. Edge energy values of $\mathrm{V}$ and Ti obtained from K-edge $\mathrm{X}$-ray absorption near edge structure (XANES) spectra of tanzanite samples before and after the heating experiment.

\begin{tabular}{ccccc}
\hline \multirow{2}{*}{ Samples } & \multicolumn{2}{c}{ Edge Energy of V (eV) } & \multicolumn{2}{c}{ Edge Energy of Ti (eV) } \\
\cline { 2 - 5 } & Before & After & Before & After \\
\hline T04 & 5479.00 & 5479.02 & 4981.92 & 4979.20 \\
\hline T06 & 5478.95 & 5479.15 & 4981.00 & 4980.70 \\
\hline T09 & 5478.82 & 5478.97 & 4981.40 & 4980.90 \\
\hline T11 & 5478.75 & 5479.02 & 4980.83 & 4979.30 \\
\hline T12 & 5478.80 & 5478.95 & 4980.73 & 4980.63 \\
\hline
\end{tabular}

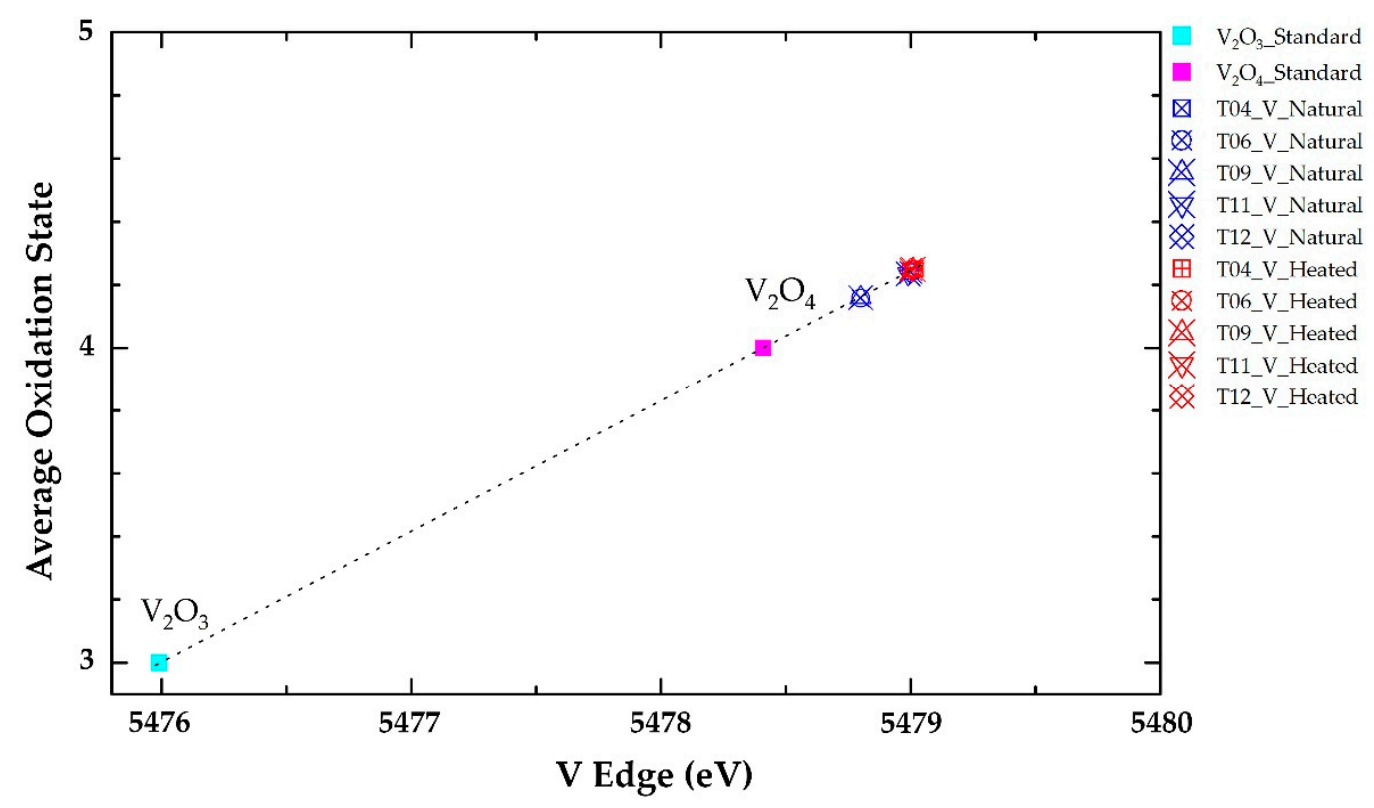

Figure 5. Plots of absorption edge energy (E0) of vanadium in natural tanzanite samples and after heating experiment with a calibration curve (dotted line) fitted by standard $\mathrm{V}_{2} \mathrm{O}_{3}$ and $\mathrm{V}_{2} \mathrm{O}_{4}$; oxidation states of vanadium in most samples appear to increase after heating. 


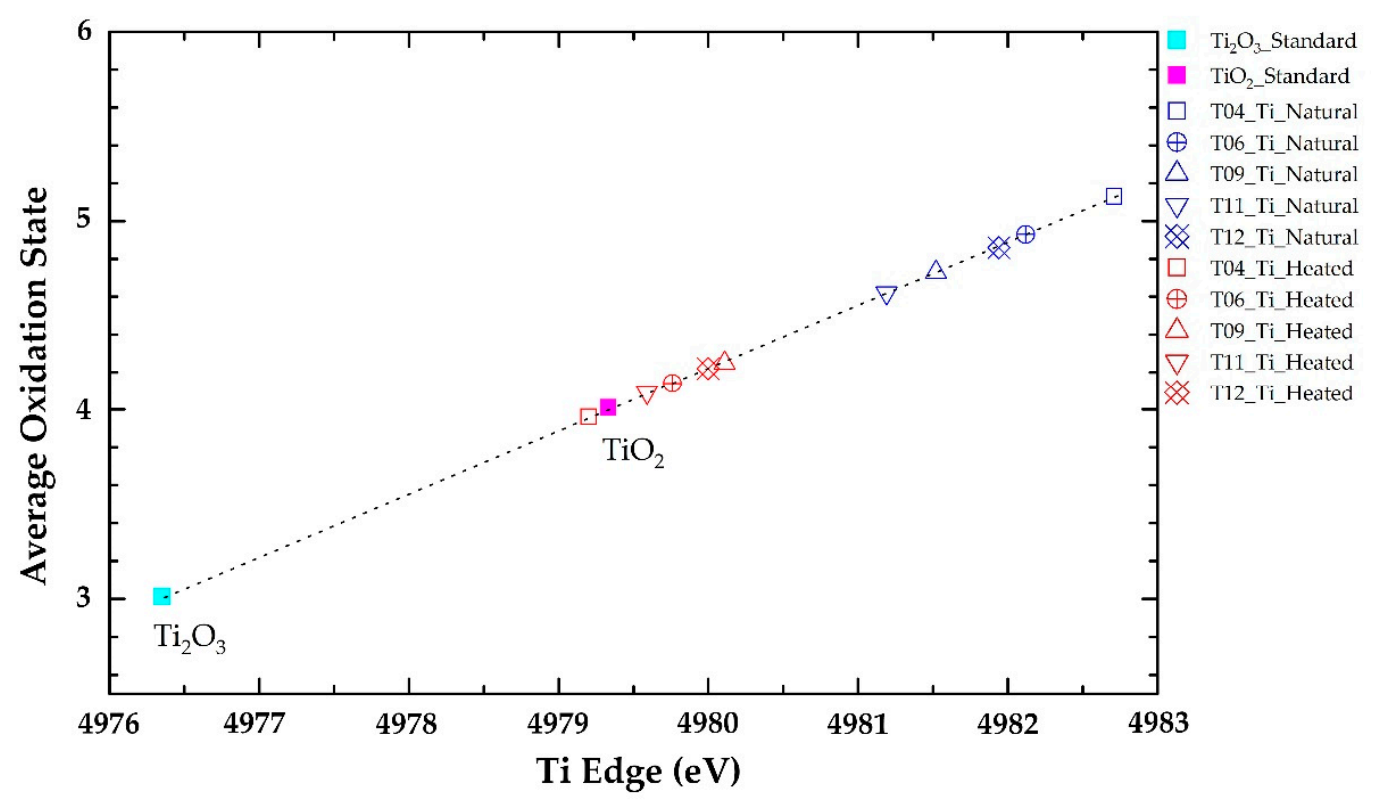

Figure 6. Plots of absorption edge energy (E0) of titanium in natural tanzanite samples and after heating experiment with a calibration curve (dotted line) fitted by standard $\mathrm{Ti}_{2} \mathrm{O}_{3}$ and $\mathrm{TiO}_{2}$; oxidation states of titanium tend to decrease after heating.

\section{Discussion}

V and Ti have previously been proposed to be the main chromophore allocated within Al-octahedral site of tanzanite; both elements could have changed oxidation states after heating [3,5,7,12-14]. $\mathrm{V}^{3+}$ should be oxidized to $\mathrm{V}^{4+}$ after heating and cause a sapphire-like blue color [2,5,11,14]. However, Olivier [3] has later suggested that heating could oxidize Ti rather than vanadium in tanzanite. He has also proposed that $\mathrm{Ti}^{3+}$ is responsible for the red/green/blue color in the natural tanzanite and appears to be oxidized to colorless $\mathrm{Ti}^{4+}$ after heating.

On the basis of the results of this investigation, natural tanzanite showed a mainly purplish blue, green-blue to green-yellow, and yellow to yellowish orange in the a-, b-, and c-axes, respectively. After the heating experiment, the yellow to yellowish orange color along the c-axis turned into violet and the bluish purple changed to violet along the a-axis, whereas the yellowish/greenish blue was altered to a blue-dominated color in the b-axis. Consequently, its pleochroism changed from trichroic to dichroic coloration, accordingly. Therefore, green and/or yellow colors were conclusively removed by heating at $550{ }^{\circ} \mathrm{C}$ (see Figure 3). The most significant change can be observed along the c-axis, which contained the most intense yellow component in the natural stone.

In general, different absorption spectra of natural tanzanite samples appear in each particular direction (a-, b-, or c-axis), for example, in sample T04 (Figure 4). A strong absorption band in the yellow region (peak at 585-600 $\mathrm{nm}$ ) can be recognized in all directions. This absorption band should involve violet coloration, which can be explained using the role of complementary colors suggested by Nassau [24]. The visible color spectrum arranged in the triangular presents pairs of complementary colors on the opposite side such as blue-orange, green-red, and yellow-violet. Each pair of complementary colors provides a white color or no color. Therefore, selective absorptions in the visible spectrum may yield the combination of colors of which their complementary pairs are absorbed [24]. The main absorption band with a peak at about 585-600 nm (yellow range) still remains after heating; therefore, it should be the main cause of violet coloration, particularly in heated tanzanite. For instance, violet (V7/4 in sample T04) appears along a- and c-axes, which is clearly caused by such an absorption band (see Figure $4 \mathrm{a}, \mathrm{c}$ ). On the other hand, the peak of this absorption band slightly 
shifts towards the orange range $(600 \mathrm{~nm})$ in the b-axis (see Figure $4 \mathrm{~b}$ ), which leads to bluish violet (bV5/5) being present, based on the same principle.

Regarding colors in natural samples, the yellowish orange (yO 6/4) color of natural tanzanite sample T04 in the c-axis is clearly effected by very strong absorption band peaked around $460 \mathrm{~nm}$ covering the blue region (Figure $4 \mathrm{c}$ ), which this absorption pattern decreases significantly in both the aand b-axes, yielding bluish purple (bP 6/3) and green-blue (GB 6/1), respectively. This absorption band is clearly an indication of natural tanzanite (unheated), as also suggested by previous workers [3,5,12-17].

Consequently, it is implicit that the trichroic bluish purple, green-blue to green-yellow, and yellow to yellowish orange colors of the a-, b-, and c-axes of natural tanzanite are obviously influenced by different intensities of absorption band (peaked around $460 \mathrm{~nm}$ ) in the blue region, as explained above. This absorption band is absent in all directions after heating at $550{ }^{\circ} \mathrm{C}$, which leads to dichroic violet (a- and c-axes) and blue (b-axis). In addition, a more stable absorption band in the yellow region (peak at 585-600 nm) presented in all directions of both natural and heated tanzanite should be the main color causing blue-violet. A slight shifting of the peak of this absorption band from 585 to $600 \mathrm{~nm}$ may induce different shades such as purplish to bluish, accordingly.

XAS analyses give rise to new evidence indicating that the edge energy of vanadium in most samples changes to the higher oxidation state, whereas titanium yields lower edge energy and decreases the oxidation state after heat treatment (Table 3, Figures 5 and 6). It has been suggested by Olivier [3] that $\mathrm{Ti}^{3+}$ causing red/green/blue color in natural tanzanite should be oxidized to $\mathrm{Ti}^{4+}$, then contributing no color. However, the results obtained from this study indicate that the oxidation state of titanium is likely decreased after heat treatment. In fact, this study reveals the increasing of vanadium edge energy in most samples, which clearly relates to more intense violet and blue coloration, which is a result of extreme decreasing of absorption in the blue region.

EPMA analyses indicate that all tanzanite samples are similar in composition and close to the idealized formula $\mathrm{Ca}_{2} \mathrm{Al}_{3}\left[\mathrm{Si}_{2} \mathrm{O}_{7}\right]\left[\mathrm{SiO}_{4}\right] \mathrm{O}(\mathrm{OH})$. Their major compositions are composed, on the basis of 13 oxygen atoms, of $\mathrm{Si}(3.1-3.2 \mathrm{apfu}), \mathrm{Al}(3.1 \mathrm{apfu})$, and $\mathrm{Ca}(2.0-2.1 \mathrm{apfu})$. Moreover, they also confirm that vanadium contents (up to $0.027 \mathrm{apfu}$ ) are much higher than titanium ( $\leq 0.002 \mathrm{apfu}$ ) in these tanzanite samples (see Table 2). Electron microprobe analyses of tanzanite in this present work represent the average results of $0.29 \mathrm{wt} \% \mathrm{~V}_{2} \mathrm{O}_{3}, 0.01 \mathrm{wt} \% \mathrm{TiO}_{2}, 0.03 \mathrm{wt} \% \mathrm{Cr}_{2} \mathrm{O}_{3}$, and $0.01 \mathrm{wt} \% \mathrm{FeO}$, which are compatible with those recently reported by Bocchio et al. [17], including about $0.39 \mathrm{wt} \%$ $\mathrm{V}_{2} \mathrm{O}_{3}, 0.01 \mathrm{wt} \% \mathrm{TiO}_{2}, 0.07 \mathrm{wt} \% \mathrm{Cr}_{2} \mathrm{O}_{3}$, and $0.00 \mathrm{wt} \% \mathrm{FeO}$, as well as those of Barot and Boehm [15], who earlier presented averages of $0.15 \mathrm{wt} \% \mathrm{~V}_{2} \mathrm{O}_{3}, 0.03 \mathrm{wt} \% \mathrm{TiO}_{2}, 0.08 \mathrm{wt} \% \mathrm{Cr}_{2} \mathrm{O}_{3}$, and $0.01 \mathrm{wt} \% \mathrm{Fe}_{2} \mathrm{O}_{3}$. However, it is in contrast to those reported by Olivier [3], who presented the lower average $\mathrm{V}_{2} \mathrm{O}_{3}$ contents of $0.06 \mathrm{wt} \%$, but comparable averages of $0.03 \mathrm{wt} \% \mathrm{TiO}_{2}, 0.04 \mathrm{wt} \% \mathrm{Cr}_{2} \mathrm{O}_{3}$, and $0.02 \mathrm{wt} \% \mathrm{FeO}$.

$\mathrm{V} / \mathrm{Ti}$ ratios obtained from this work show that $\mathrm{V}$ contents are about 13 to 40 times greater than Ti content, which fits well with the color-causing model of tanzanites. $\mathrm{V}$ content was quoted to be 60 times greater than Ti content in blue colored samples, but decreasing to 16 to 5 times was observed in yellowish brown and greenish yellow colored zoisites [3,13,17]. Moreover, the $\mathrm{V}_{2} \mathrm{O}_{3} / \mathrm{Cr}_{2} \mathrm{O}_{3}$ ratios of all tanzanites in this work are greater than two, which typically yields a blue color, whereas lower than two is usually detected in green tanzanite [25]. Therefore, it is clear that the main chromophore in these samples is vanadium, which appears to have contributed to violet and blue coloration after heat treatment.

\section{Materials and Methods}

Five rough tanzanite samples were collected based on their strong trichroism, which clearly showed various colors in different directions. During rotation of the sample, color changing was clearly observed such as yellowish orange to orangey yellow, greenish yellow to greenish blue to bluish green, and bluish purple along particularly directions, which were marked. Subsequently, samples were then cut and polished following those marked directions and their colors were compared with the GIA standard color GemSet. Colors along these particular directions were also observed again after 
heating experiment. In addition, absorption spectra were analyzed using a PerkinElmer-LAMBDA 900 UV/VIS/NIR spectrophotometer based at Department of Earth Sciences, Kasetsart University (PerkinElmer LAMBDA, Waltham, MA, USA); the operating conditions were set with 2.00 slit size and recording range between $200 \mathrm{~nm}$ and $1500 \mathrm{~nm}$. Chemical compositions of the samples were analyzed using an electron probe microanalyzer (EPMA), JEOL model JXA 8100 (Musashino, Akishima-shi, Tokyo, Japan), while the heating experiment was carried out using a Linn-HT-1800-Vac high temperature furnace (Linn High Therm, Frankenhausen, Germany). Both EPMA and high temperature furnace were facilitated by Department of Geology, Chulalongkorn University. Analytical conditions of EPMA were set at $15 \mathrm{kV}$ accelerating voltage and about $2.5 \times 10^{-8}$ A probe current with focus electron beam $(<1 \mu \mathrm{m})$. Mineral standards and some synthetic oxide standards were selected appropriately for calibration including jadeite $\left(\mathrm{NaAlSi}_{2} \mathrm{O}_{5}\right)$ for $\mathrm{Na}$, fayalite $\left(\mathrm{Fe}_{2} \mathrm{SiO}_{4}\right)$ for $\mathrm{Fe}$, wallastonite $\left(\mathrm{CaSiO}_{3}\right)$ and potassium titanium phosonate $\left(\mathrm{KTiPO}_{4}\right)$ for $\mathrm{Ti}$ and $\mathrm{K}$, synthetic corundum $\left(\mathrm{Al}_{2} \mathrm{O}_{3}\right)$ for $\mathrm{Al}$, synthetic periclase $(\mathrm{MgO})$ for $\mathrm{Mg}$, synthetic quartz $\left(\mathrm{SiO}_{2}\right)$ for $\mathrm{Si}$, synthetic manganesite $(\mathrm{MnO})$ for $\mathrm{Mn}$, synthetic eskolaite $\left(\mathrm{Cr}_{2} \mathrm{O}_{3}\right)$ for $\mathrm{Cr}$, and lead vanadium germanium oxide (PbV Geoxide) for $\mathrm{V}$. The heating experiment was carried out in atmospheric condition at the maximum temperature of $550{ }^{\circ} \mathrm{C}$ with approximately a $1.8^{\circ} \mathrm{C} / \mathrm{min}$ heating rate without holding time prior to cooling down naturally in the furnace. XAS was investigated at Beamline 1.1W: Multiple X-ray Techniques (MXT) experimental station (Nakhon Ratchasima, Thailand) at the Synchrotron Light Research Institute (Public Organization) in Thailand (Figure 7). This beamline has a 2.2 Tesla multipole wiggle as the X-ray source and equipped with Si (111) double monochromator. A 19-element Ge detector was used as a florescence detector to detect probed element with low concentration. All XAS analyses were examined using $1.65(\mathrm{~V}) \times 2.6(\mathrm{H}) \mathrm{mm}$ beam size along the $\mathrm{C}$-axis in all samples with an average of three scans to improve signal to noise ratio. A standard foil for each element was used to calibrate $X$-ray energies by setting the absorption edge energy of $\mathrm{V}$ and $\mathrm{Ti}$ to $5465 \mathrm{eV}$ and $4966 \mathrm{eV}$, respectively. An energy scan ranging from $200 \mathrm{eV}$ below to $200 \mathrm{eV}$ above the absorption edge energy was used with the highest collection time of $2 \mathrm{~s}$ and $7 \mathrm{~s}$ per point for vanadium and titanium, respectively. Furthermore, $\mathrm{V}_{2} \mathrm{O}_{3}, \mathrm{~V}_{2} \mathrm{O}_{4}, \mathrm{Ti}_{2} \mathrm{O}_{3}$, and $\mathrm{TiO}_{2}$ were measured as chemical standards in transmission mode using ionization chambers. However, these standards are not the same mineral group as tanzanite, and thus are used as a reference point for relative change, but are unable to inform the exact oxidation state of $\mathrm{V}$ and $\mathrm{Ti}$ in the samples. The absorption edges of $\mathrm{V}$ and $\mathrm{Ti}$ from XANES spectra were then extracted from their first derivative graph and presented in a calibration curve. 


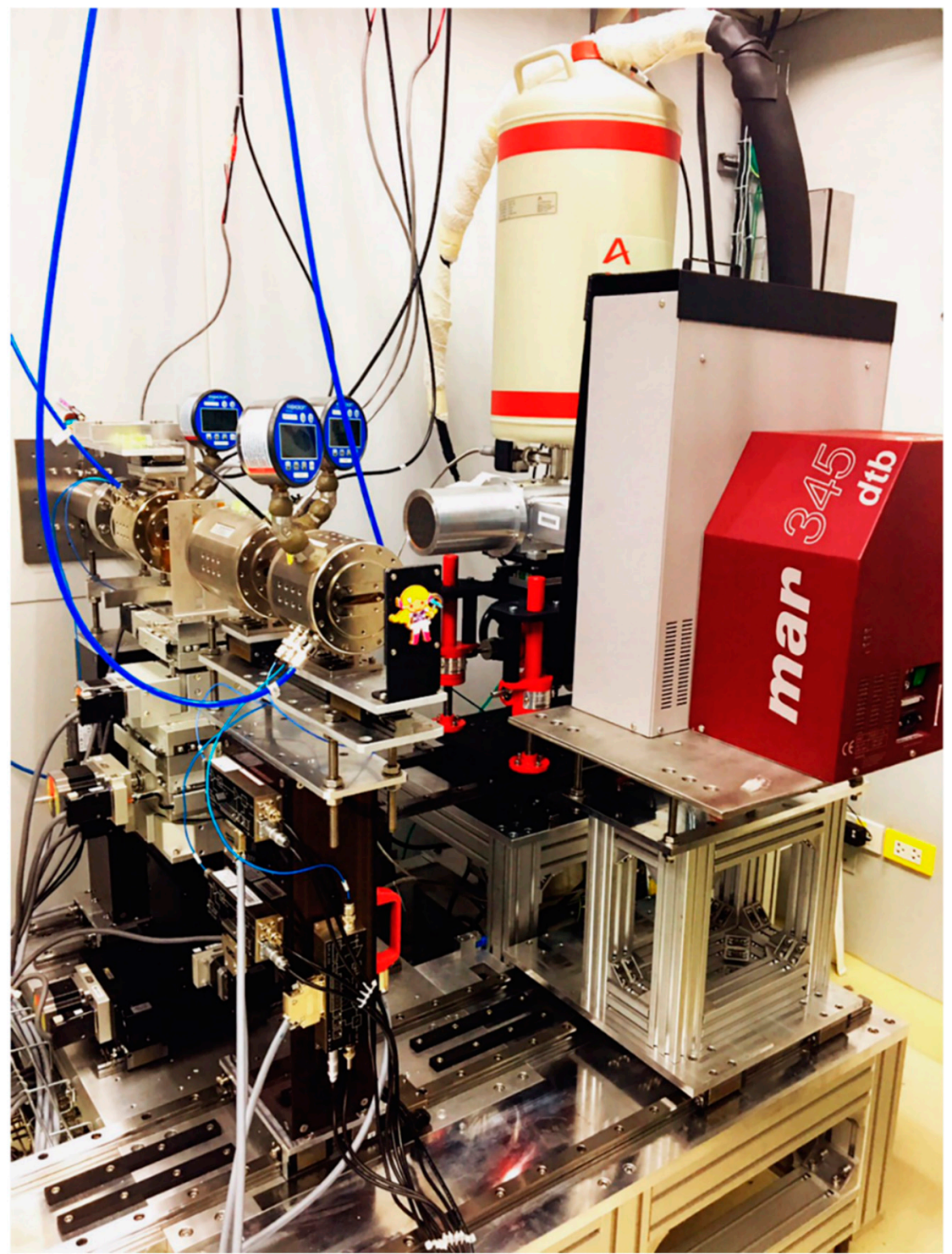

Figure 7. Beamline 1.1W: Multiple X-ray Technique station (photo by C. Saiyasombat).

\section{Conclusions}

Physical and chemical properties of the studied tanzanites were observed and measured using basic and advanced gemological instruments in combination with X-ray absorption spectroscopy (XAS). These results can be used to demonstrate the coloration in natural and heat-treated tanzanites, which can be recapitulated as follows.

(I) More desired violet-blue color in tanzanite can be improved by thermal process; (II) the absorption band with a peak around $460 \mathrm{~nm}$ (blue range) is the main cause of color in different directions (trichroism) of natural tanzanite, whereas the absorption band in the yellow region (peak at 585-600 nm) similarly presents in all directions and still remains after heating; (III) after heating, the c-axis shows the most significant change in color compared with the other directions-it clearly relates to the disappearance of the $460 \mathrm{~nm}$ absorption band; and (IV) XAS spectra show an increasing of edge energy of vanadium, which indicates the higher oxidation state after heat treatment-this should cause the disappearance of the $460 \mathrm{~nm}$ absorption band and induce more intensive blue-violet color in heated tanzanites. 
Author Contributions: Data curation, C.S. (Chatree Saiyasombat) and C.S. (Chakkaphan Sutthirat); Investigation, T.P.; Methodology, T.P.; Project administration, C.S. (Chakkaphan Sutthirat); Resources, B.W. and C.S. (Chakkaphan Sutthirat); Supervision, C.S. (Chakkaphan Sutthirat); Visualization, C.S. (Chatree Saiyasombat) and C.S. (Chakkaphan Sutthirat); Writing—original draft, T.P.; Writing—review \& editing, B.W., C.S. (Chatree Saiyasombat) and C.S. (Chakkaphan Sutthirat). All authors have read and agreed to the published version of the manuscript.

Funding: This research was funded by the 100th Anniversary Chulalongkorn University Fund for Doctoral Scholarship.

Acknowledgments: We acknowledge the Synchrotron Light Research Institute (Public Organization), SLRI, particularly all staffs of the beamline 1.1W (MXT) and the team of Synchrotron Technology Innovation for Gemology and Mineralogy for their technical support. Special thank is sent to Sopit Poompeang for assistance in EPMA analyses as well as Ekkasit Sirisurawong for all collaboration during XAS investigation.

Conflicts of Interest: The authors declare no conflict of interest. The funders had no role in the design of the study; in the collection, analyses, or interpretation of data; in the writing of the manuscript; or in the decision to publish the results.

\section{References}

1. Deer, W.A.; Howie, R.A.; Zussman, J. An Introduction to the Rock-Forming Minerals, 3rd ed.; Berforts Information Press: Hastings, UK, 2013.

2. Crowningshield, R. Zoisite Crystals. Gems Gemol. 1967, 12, 201-202.

3. Olivier, B. The Geology and Petrology of the Merelani Tanzanite Deposit, NE Tanzania. Ph.D. Thesis, Stellenbosch University, Stellenbosch Central, Stellenbosch, South Africa, December 2006.

4. Dollase, W.A. Refinement and comparison of the structure of zoisite and clinozoisite. Am. Min. 1968, 53, 1882-1898.

5. Hurlbut, C.S. Gem zoisite from Tanzania. Am. Min. 1969, 54, 702-709.

6. Ghose, S.; Tsang, T. Ordering of $\mathrm{V}^{2+}, \mathrm{Mn}^{2+}$, and $\mathrm{Fe}^{3+}$ Ions in Zoisite, $\mathrm{Ca}_{2} \mathrm{Al}_{3} \mathrm{Si}_{3} \mathrm{O}_{12}(\mathrm{OH})$. Science 1971, 171, 374-376. [CrossRef] [PubMed]

7. Franz, G.; Liebscher, A. Physical and Chemical Properties of the Epidote Minerals-An Introduction. Rev. Mineral. Geochem. 2004, 56, 1-82. [CrossRef]

8. Armbruster, T.; Bonazzi, P.; Akasaka, M.; Bermanec, V.; Chopin, C.; Giere, R.; Heuss-Assbichler, S.; Liebscher, A.; Menchetti, S.; Pan, Y.; et al. Recommended nomenclature of Epidote-group minerals. Eur. J. Mineral. 2006, 18, 551-567. [CrossRef]

9. Mills, S.J.; Hatert, F.; Nickel, E.H.; Ferraris, G. The standardization of mineral group hierarchies: Application to recent nomenclature proposals. Eur. J. Mineral. 2009, 21, 1073-1080. [CrossRef]

10. Lauf, R.J. Collector's Guide to Epidote Group; Schiffer Publishing: Pennsylvania, PA, USA, 2011.

11. McClure, S.F.; Smith, C.P. Gemstone enhancement and detection in the 1990s. Gems Gemol. 2000, 36, 341. [CrossRef]

12. Anderson, B.W. Three items of interest to gemmologists. J. Gemmol. 1968, 11, 1-6. [CrossRef]

13. Faye, G.H.; Nickel, E.H. On the pleochroism of vanadium-bearing zoisite from Tanzania. Can. Mineral. 1971, 10, 812-821.

14. Schmetzer, K.; Bank, H. Bluish-green zoisite. Gems Gemol. 1979, 16, 121-122.

15. Barot, N.R.; Boehm, E.W. Gem-quality green zoisite. Gems Gemol. 1992, 28, 4-15. [CrossRef]

16. Smith, C.P. Natural-Color Tanzanite. Gems Gemol. 2011, 47, 119-120.

17. Bocchio, R.; Adamo, I.; Bordoni, V.; Caucia, F.; Diella, V. Gem-quality zoisite from Merelani (Northeastern Tanzania): Review and new data. Period Mineral. 2012, 81, 379-391.

18. Fridrichova, J.; Bacik, P.; Rusinova, P.; Antal, P. Optical and crystal-chemical changes in aquamarines and yellow beryls from Thanh Hoa province, Vietnam induced by heat treatment. Phys. Chem. Miner. 2015, 42, 287-302. [CrossRef]

19. Garcia-Guinea, J.; Correcher, V.; Rubio, J.; Valle-Fuentes, F.J. Effects of preheating on diaspore: Modifications in colour centres, structure and light emission. J. Phys. Chem. Solids 2005, 66, 1220-1227. [CrossRef]

20. Newville, M. Fundamentals of XAFS. Rev. Mineral. Geochem. 2004, 78, 33-74. [CrossRef]

21. Bare, S.R. Introduction to X-ray Absorption Spectroscopy. 2007 APS XAFS Summer School [Online], July 23, 2007. Center for Advanced Radiation Sources. Available online: https:/millenia.cars.aps.anl.gov/xafs/ Workshops/APS2007?action=AttachFile\&do=view\&target=Bare_Intro.pdf (accessed on 7 October 2019). 
22. Ruiz, J.G. Applications of X-ray Absorption Spectroscopy in Physics and Material Science. IUCr 2011 XAFS Tutorial [Online], August 30, 2011. International Union of Crystallography. Available online: https: //www.iucr.org/_data/assets/pdf_file/0009/60984/IUCr2011-XAFS-Tutorial-J-Garcia-Ruiz.pdf (accessed on 22 October 2019).

23. Ravel, B. Introduction to X-ray Absorption Spectroscopy. Center for Functional Nanomaterials (CFN) and National Synchrotron Light Source II (NSLS-II) Lecture Series [Online], September 30, 2015. Brookhaven National Laboratory. Available online: https:/www.bnl.gov/ps/userguide/lectures/Lecture-4-Ravel.pdf (accessed on 29 October 2019).

24. Nassau, K. The Physics and Chemistry of Color: The Fifteen Causes of Color, 2nd ed.; A Wiley-Interscience Publication: New York, NY, USA, 2001.

25. Kammerling, R.C.; Koivula, J.I.; Johnson, M.L.; DeGhionno, D.; Hanni, H.A.; Schmetzer, K. Gem News: Tanzanites and other zoisites from Merelani, Tanzania. Gems Gemol. 1995, 31, 285.

Sample Availability: Tanzanites samples are available from Dr. Bhuwadol Wanthanachaisaeng.

(C) 2020 by the authors. Licensee MDPI, Basel, Switzerland. This article is an open access article distributed under the terms and conditions of the Creative Commons Attribution (CC BY) license (http://creativecommons.org/licenses/by/4.0/). 